\title{
Badania nad opracowaniem hybrydowej cieczy buforowej
}

\section{Research into the development of a hybrid spacer}

\author{
Marcin Kremieniewski, Miłosz Kędzierski \\ Instytut Nafty i Gazu - Państwowy Instytut Badawczy
}

\begin{abstract}
STRESZCZENIE: W trakcie tłoczenia zaczynu cementowego w wypełnianej nim przestrzeni pierścieniowej usuwana jest płuczka wiertnicza. Tłoczony po płuczce zaczyn cementowy usuwa pozostałości osadu płuczkowego. W celu dobrego uszczelnienia otworu zaczynem, który po związaniu uniemożliwi przepływ gazu, niezbędne jest dokładne oczyszczenie przestrzeni pierścieniowej z osadu płuczkowego poprzez przetłoczenie sekwencji cieczy wyprzedzających. W pierwszej kolejności tłoczona jest ciecz przemywająca, następnie ciecz buforowa, a po niej tłoczony jest zaczyn cementowy. Uzyskanie odpowiednio oczyszczonej przestrzeni pierścieniowej przed zabiegiem cementowania niewątpliwie wpływa na poprawę uszczelnienia i pozwala wyeliminować lub ograniczyć ewentualności zachodzenia niepożądanego zjawiska mikroprzepływów gazu w przestrzeni pierścieniowej. Jednak tłoczenie cieczy przemywającej w celu zdyspergowania pozostałości osadu płuczkowego, a następnie tłoczenie po niej cieczy buforowej, która wyrównuje parametry reologiczne pomiędzy tłoczonymi cieczami wiertniczymi (niskolepka przemywka - zaczyn cementowy o znacznie większej lepkości plastycznej), powoduje wzrost kosztów zabiegu cementowania. W związku z powyższym postanowiono przeprowadzić prace badawcze nad opracowaniem hybrydowej cieczy buforowej. Zamysł prac badawczych był taki, aby ciecz buforowa posiadała dwufunkcyjny charakter. Z jednej strony hybrydowa ciecz buforowa miała spełniać rolę cieczy buforowej (odpowiednio dobrana gęstość, lepkość i wytrzymałość strukturalna), a z drugiej strony zawarte w cieczy buforowej środki powierzchniowo czynne miały za zadanie oczyszczać przygotowywaną do cementowania przestrzeń pierścieniową. Zastosowanie takiej cieczy powoduje obniżenie kosztów oraz skrócenie czasu przygotowania do zabiegu cementowania. W niniejszym artykule przedstawiono wyniki badań nad opracowaniem hybrydowej cieczy buforowej. Przeprowadzone zostały badania oczyszczania przestrzeni pierścieniowej w symulowanych warunkach otworowych. Uzyskane wyniki badań pozwoliły stwierdzić, że opracowana hybrydowa ciecz buforowa wykazuje dwufunkcyjne właściwości i widoczna jest poprawa oczyszczenia powierzchni formacji skalnej w porównaniu do dotychczas stosowanych cieczy przemywających. Niestety stwierdzono również problem dotyczący znacznego żelowania płuczki podczas kontaktu z obecnym w cieczy buforowej cementem. Należy zaznaczyć, iż były to badania pilotażowe, w których osiągnięto tylko częściowe rozwiązanie problemu. Opracowana hybrydowa ciecz buforowa wymaga dalszych badań, które pozwolą wyeliminować żelowanie płuczki podczas kontaktu z tą cieczą. Omówione zagadnienie pozwala przybliżyć badaczom poruszaną problematykę, dzięki czemu w przyszłości możliwe będzie dokładniejsze rozpracowanie danego zagadnienia.
\end{abstract}

Słowa kluczowe: hybrydowa ciecz buforowa, bufor, ciecz wyprzedzająca, oczyszczanie przestrzeni pierścieniowej, poprawa skuteczności zacementowania, ciecz dwufunkcyjna.

ABSTRACT: While the cement slurry is being pumped, the drilling mud is removed in the annular space filled with it. The cement slurry pressed after the mud removes residues of mud sludge. In order to properly seal the borehole with cement slurry, which will prevent gas flow after binding, it is necessary to thoroughly clean the annular space from the mud sludge by pumping the sequence of preflush. First, the washing liquid is pumped, then the spacer, followed by the cement slurry. Obtaining a properly cleaned annular space before cementing undoubtedly improves sealing and allows to eliminate or reduce the possibility of the undesirable phenomenon of gas micro flows in the annular space. However, pressing the washing liquid to disperse the residue of the sludge and then pressing the spacer after it, which equalizes the rheological parameters between the pressed drilling fluids (low-viscous washing - cement slurry with much higher plastic viscosity) causes an increase in the costs of cementing. Therefore, it was decided to carry out research on the development of a hybrid spacer. The idea of research was that the spacer had a dual-purpose nature. On the one hand, the hybrid liquid was to act as a spacer (properly selected density, viscosity and structural strength), and on the other hand, the surfactants contained in the spacer were to clean the annular space prepared for cementation. The use of such a liquid reduces costs and shortens the preparation time for cementing. This article presents the results of research on the development of a hybrid spacer. Annular space purification studies were performed under simulated borehole conditions. The obtained research results allowed to state that the developed hybrid spacer has bifunctional properties and an improvement in the cleaning of the rock formation surface is visible compared to the washing liquids used so far. Unfortunately, a problem was also found regarding significant gelation of the mud during contact with the cement

Autor do korespondencji: M. Kremieniewski, e-mail: marcin.kremieniewski@inig.pl

Artykuł nadesłano do Redakcji: 04.03.2020 r. Zatwierdzono do druku: 16.07.2020 r. 
present in the spacer. It should be noted that these were pilot studies in which only a partial solution to the problem was achieved. The developed hybrid spacer requires further research to eliminate gelation of the mud during contact with the hybrid spacer. The discussed issue allows researchers themselves to familiarize themselves with the discussed subject, thanks to which in the future it will be possible to further develop given issues.

Key words: hybrid spacer, spacer, preflush, cleaning of the annular space, improvement of cementing efficiency, bifunctional liquid.

\section{Wprowadzenie}

Bufory to rodzaj cieczy wyprzedzających, charakteryzujących się szczególnymi właściwościami reologicznymi oraz określoną gęstością. Ciecze buforowe zawierają znacznie więcej fazy stałej niż ciecze przemywające. Są one najbardziej efektywnymi płynami rozdzielającymi zaczyn cementowy i płuczkę wiertniczą (Błaż, 2017; Kremieniewski i Rzepka, 2018; Moradi i Nikolaev, 2018). Bufor wtłaczany do przestrzeni pierścieniowej otworu przy burzliwym charakterze przepływu (podobnie jak ciecz przemywająca) powoduje pewnego rodzaju przemywanie ściany otworu, lecz w mniejszym stopniu niż ma to miejsce podczas tłoczenia cieczy przemywającej. Głównym celem tłoczenia cieczy buforowej jest wypieranie płuczki (Wang et al., 2014; Curbelo et al., 2018; Kremieniewski et al., 2018b). W praktyce stwierdzono, że najlepsze usuwanie płuczki (wypieranie) ma miejsce, gdy gęstość buforu jest nieco większa od gęstości płuczki, ale niższa od gęstości zaczynu cementowego (Bakirov et al., 2019). Usuwaniu płuczki towarzyszy wówczas efekt wyporności. Najskuteczniejszym przepływem buforu, przy którym uzyskuje się dobre usuwanie płuczki i oczyszczanie przestrzeni pierścieniowej jest przepływ turbulentny (Herman, 1995a, 1995b; Zima, 2014; Uliasz et al., 2006). Należy pamiętać, że lepkość buforu powinna być odpowiednio dobrana tak, aby uzyskać turbulentny przepływ przy optymalnym jego natężeniu tłoczenia. Istotne jest, aby lepkość miała odpowiednią wartość również po wprowadzeniu do cieczy buforowej materiałów obciążających (Kremieniewski i Rzepka, 2016). W celu spełnienia tych bardzo trudnych wymagań stosuje się różnego rodzaju środki polimerowe. Korzyścią z tłoczenia cieczy buforowej przy przepływie turbulentnym jest możliwość utrzymania cząstek materiałów obciążających w zawiesinie, dzięki czemu nie następuje wytrącanie i sedymentacja (Kremieniewski i Kędzierski, 2019; Kremieniewski, 2020). Niekiedy stosowanie odpowiednich natężeń przepływu w celu uzyskania przepływu turbulentnego napotkać może na ograniczenia w postaci wytrzymałości ciśnieniowej osprzętu cementacyjnego lub zaistnienia ewentualności przekroczenia ciśnienia szczelinowania formacji skalnej. W takich przypadkach wymagane jest stosowanie cieczy buforowych, które tłoczone będą w warunkach przepływu laminarnego (Nelson, 1990).

Tłoczony w celu uszczelnienia przestrzeni pierścieniowej zaczyn, na skutek kontaktu z płuczką wiertniczą może tworzyć trudno przetłaczalną masę (Kędzierski et al., 2019). Najczęściej jest to konsekwencją zachodzących reakcji chemicznych w strefie kontaktu płuczki i zaczynu (Habrat, 1980; Kremieniewski, 2016; Kremieniewski et al., 2016). Utrudniona przetłaczalność zaczynu wymusza zastosowanie znacznie większego ciśnienia tłoczenia zaczynu. Konsekwencją powyższego może być wprowadzanie w strefę przyodwiertową dodatkowej objętości filtratu z płuczki wiertniczej i z zaczynu cementowego, a tym samym pogorszenie przepuszczalności strefy przyodwiertowej (Uliasz et al., 2012; Kremieniewski i Stryczek, 2019). Ponadto wysokie wartości ciśnienia tłoczenia zwiększają ryzyko szczelinowania skał słabozwięzłych (Habrat, 1980).

W celu wyeliminowania powyższych niekorzystnych zjawisk powstających na skutek zanieczyszczenia zaczynu cementowego przez płuczkę wiertniczą stosuje się ciecze buforowe, których jednym z zadań jest również rozdzielenie poszczególnych cieczy wiertniczych (płuczki i zaczynu cementowego). Dodatkowym zadaniem cieczy buforowej jest łatwiejsze wyparcie płuczki z przestrzeni pierścieniowej, a także usunięcie pozostałości osadu filtracyjnego ze ścian otworu i kolumny rur okładzinowych (Uliasz et al., 2015). Zatłaczana ciecz buforowa pozwala uzyskać wymaganą i optymalną dla danych warunków charakterystykę przepływu (przepływ turbulentny przy możliwie niewielkich prędkościach tłoczenia lub przepływ tłokowy przy dużych prędkościach tłoczenia), (Habrat 1980; Stryczek et al., 2016). Należy również wspomnieć, że ciecz buforowa umożliwia osiągnięcie odpowiedniego czasu kontaktu cieczy wyprzedzających ze skałą i rurami w cementowanym interwale przestrzeni pozarurowej, co pozwala odpowiednio nawilżyć przygotowywaną do cementowania powierzchnię (rurę okładzinową i formację skalną). Zanieczyszczony płuczką wiertniczą zaczyn cementowy charakteryzuje się nie tylko wyższymi wartościami lepkości plastycznej (co wpływa na jego gorszą przetłaczalność), lecz również obecne w płuczce środki modyfikujące jej parametry powodują zmianę czasu gęstnienia zaczynu (Kremieniewski, 2019b; Bakirov et al., 2020). Może się zdarzyć, że zaczyn będzie gęstniał znacznie szybciej i gwałtowniej, co uniemożliwi wytłoczenie zaczynu do wierzchu lub niedokładne wypełnienie przestrzeni pierścieniowej (Kremieniewski, 2019c). Istnieje również możliwość znacznego wydłużenia czasu gęstnienia zaczynu, czego konsekwencją może być powstawanie migracji i ekshalacji gazu (Uliasz et al., 2015; Kremieniewski, 2016). W otworach o podwyższonym ryzyku wystąpienia migracji, gaz może wtargnąć 
w strukturę jeszcze niezwiązanego zaczynu i tworzyć kanaliki, które będą drogą migracji i ekshalacji po związaniu zaczynu (rys. 1). Poprawa efektywności wypierania płuczki jest bardzo ważna podczas stosowania płuczek obciążonych, o dużej lepkości plastycznej i wytrzymałości strukturalnej. W przypadku wytłaczania tego rodzaju płuczek może zachodzić zjawisko kanałowania płuczki (rys. 2), czyli kanałowego przepływu zaczynu cementowego, czego efektem będzie niejednolite przylegania cementu do kolumny rur i formacji skalnej (Habrat, 1980, Kremieniewski, 2016; Stryczek et al., 2016). W warunkach stosowania płuczki obciążonej niezbędne jest zastosowanie zaczynu cementowego o wyższej gęstości, lepkości plastycznej i wytrzymałości strukturalnej. W trakcie tłoczenia takiego zaczynu utrudnione jest uzyskanie przepływu burzliwego przy niskich wartościach ciśnienia tłoczenia. Wzrost ciśnienia tłoczenia mógłby natomiast doprowadzić do rozszczelinowania skał w ścianie otworu. Zastosowanie w takim przypadku odpowiedniej cieczy buforowej pozwala ,wypośrodkować" ciśnienie tłoczenia i łagodnie przejść z prędkości tłoczenia płuczki do prędkości tłoczenia zaczynu cementowego (Kremieniewski et al., 2018a). Możliwość utrzymania wymaganych wydatków tłoczenia w cementowanej przestrzeni pierścieniowej przy dużych prędkościach przepływu uwarunkowana jest zastosowaniem cieczy buforowej o dużej wytrzymałości strukturalnej. Dodatkowo ciecz buforowa pozwala uzyskać wymagany czas trwania styku cieczy buforowej i zaczynu cementowego ze ścianą otworu i rurami okładzinowymi. Czas ten wynika z doświadczalnie i praktycznie stwierdzonej zależności stopnia wyparcia płuczki oraz oczyszczenia ściany otworu i rur oraz od długotrwałości oddziaływania cieczy wypierających na płuczkę. Oddziaływanie to może mieć charakter hydromechaniczny, fizyczny, chemiczny, reologiczny lub być składową wszystkich jednocześnie (Habrat, 1980; Stryczek i Gonet, 2005; Stryczek et al., 2016).

Skład i właściwości cieczy buforowych dobiera się indywidualnie dla danego zabiegu cementowania, stosowanej płuczki oraz zaczynu cementowego, a także po uwzględnieniu rodzaju przewiercanej formacji geologicznej. Niezależnie od własności cieczy buforowej dobieranej dla konkretnych warunków otworowych każdy bufor powinien charakteryzować się stałymi właściwościami i małym wpływem na parametry płuczek wiertniczych po zmieszaniu tych cieczy (Habrat, 1980; Stryczek et al., 2016). Nie powinien oddziaływać na czas wiązania zaczynu cementowego oraz nieznacznie oddziaływać na jego lepkość tak, aby nie zaburzyć przetłaczalności zaczynu. Dodatkowo bufor powinien posiadać dużą odpornością na działanie wysokich temperatur oraz wykazywać możliwość regulowania właściwości fizycznych, chemicznych i reologicznych. Dotyczy to głównie gęstości, lepkości i wytrzymałości strukturalnej, w zależności od wartości wymaganych w danym

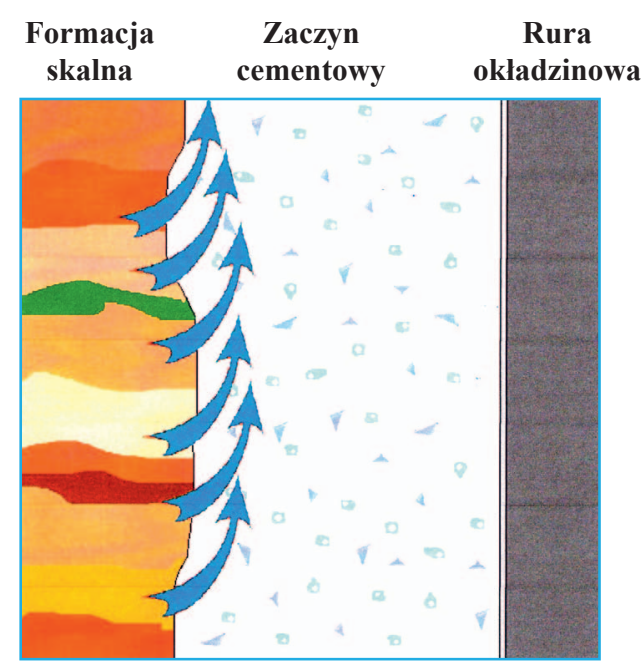

Rys. 1. Schemat wnikania gazu w strukturę wiążącego zaczynu cementowego i tworzenia się kanalików migracji gazu

Fig. 1. Diagram of gas penetration into the structure of the cementitious grout and the formation of gas migration channels

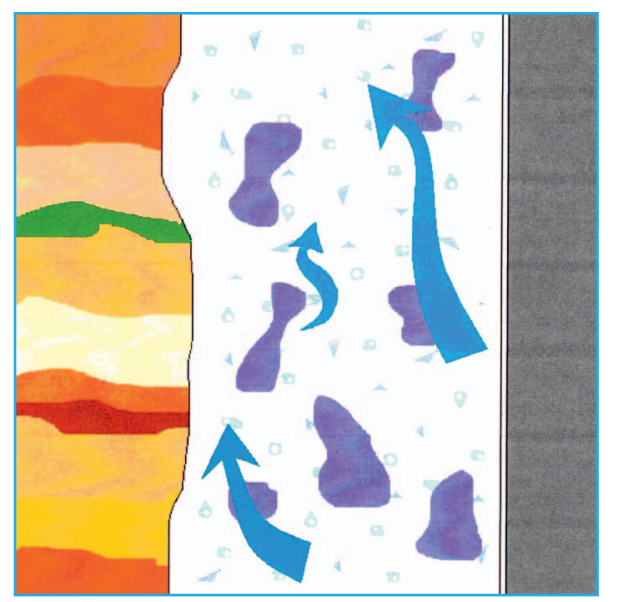

Rys. 2. Schemat kanałowego przepływu zaczynu cementowego pomiędzy zżelowanymi elementami płuczki

Fig. 2. Diagram of the cement slurry flow between the gelled mud elements

rejonie wiercenia. Nie powinien wykazywać zmian własności reologicznych pod wpływem temperatury. Wymaga się także, aby ciecz buforowa posiadała odpowiednią stabilność sedymentacyjną, pozwalającą na utrzymanie w zawieszeniu materiałów obciążających oraz charakteryzowała się możliwością ,przyjęcia” dodatkowej ilości fazy stałej, którą stanowią wymyte zwierciny oraz osad płuczkowy. Istotne jest, aby ciecz buforowa posiadała odpowiednią odporność na dodatki chemiczne (środki dyspergujące, upłynniające, opóźniające, przyspieszające, polimery i inne), które przenikają z płuczki i z zaczynu cementowego do płynnej struktury buforu (Habrat, 1980; Nelson, 1990; Kremieniewski, 2018). Ciecz buforowa powinna posiadać zdolność utrzymywania pochodzących z zaczynu cementowego jonów wapnia i nie współdziałać w tym zakresie z płuczką. Dodatkowo powinna wykazywać małą 
filtrację, nie posiadać agresywności korozyjnej w stosunku do stali i tworzywa cementowego oraz nie reagować ze składnikami skał i wód złożowych (Jasiński, 2016). Ciecze buforowe powinny być również stosunkowo łatwe do sporządzenia w warunkach otworowych.

Konkludując powyższe rozważania można stwierdzić, iż odpowiednia charakterystyka cieczy wiertniczych (począwszy od cieczy przemywających poprzez ciecze buforowe, a skończywszy na zaczynach cementowych) stanowi pewnego rodzaju wyzwanie dla specjalistów zajmujących się daną tematyką. Ciecze wiertnicze posiadają skomplikowany charakter zarówno od strony reologicznej, jak i technologicznej, co wiąże się z jednej strony z zachodzącą w czasie hydratacją cementu obecnego w cieczy buforowej czy zaczynie cementowym, a $z$ drugiej strony ze zmiennością temperatury i ciśnienia wraz ze wzrostem głębokości otworu. W związku z tym, oczywistym wydaje się być prowadzenie prac badawczo-studialnych, których celem jest śledzenie i zrozumienie zjawisk zachodzących w układach danych cieczy, co może się przyczynić do efektywności oczyszczania przestrzeni pierścieniowej. W związku z powyższym postanowiono podjąć próby nad opracowaniem hybrydowej cieczy buforowej zawierającej w swoim składzie dodatkowy zestaw środków powierzchniowo czynnych i/lub surfaktantów. Środki te dodawane są do cieczy przemywających w celu nawilżenia rur okładzinowych i formacji skalnej znajdującej się w przestrzeni pierścieniowej, a tym samym poprawy wiązania cementu (Kremieniewski, 2019a). W cieczy buforowej stanowią one natomiast dodatkowe wzmocnienie efektu wymywania pozostałości osadu płuczkowego.

W niniejszym artykule omówiono badania nad opracowaniem hybrydowej cieczy buforowej o dwufunkcyjnym charakterze. $Z$ jednej strony ciecz wykazywała charakter cieczy buforowej o gęstości wyższej niż gęstość cieczy przemywającej i podwyższonych parametrach reologicznych. Takie powinowactwo do cieczy buforowej pozwala na usunięcie płuczki wskutek efektu wyporności oraz stanowi „strefę przejściową" od niskich wartości parametrów reologicznych oraz gęstości płuczki do wysokich parametrów reologicznych i gęstości zaczynu cementowego. Z drugiej strony dodatkowe wzbogacenie cieczy buforowej przez komponenty cieczy przemywającej miały za zadanie zbliżyć charakterystykę cieczy buforowej do charakterystyki cieczy przemywającej. Obecność środków powierzchniowo czynnych i/lub surfaktantów pozwoliła na skuteczniejsze zdyspergowanie pozostałego osadu płuczkowego. Natomiast obecność domieszek superplastyfikatorów pozwoliła wytworzyć powinowactwo cieczy buforowej do cieczy przemywającej wskutek obniżenia parametrów reologicznych. Jednakże niskie wartości parametrów reologicznych wymagały zastosowania dodatkowych środków w celu wytworzenia w opracowywanej cieczy zawiesiny przeciwdziałającej sedymentacji obecnych w cieczy ciężkich cząstek ciała stałego.

\section{Prace badawcze}

Prace badawcze nad opracowaniem hybrydowej cieczy buforowej przeprowadzono w Laboratorium Zaczynów Uszczelniających INiG - PIB w oparciu o normy: PN85/G-02320 Cementy i zaczyny cementowe do cementowania w otworach wiertniczych; PN-EN 10426-2 Przemyst naftowy i gazowniczy. Cementy i materiaty do cementowania otworów. Część 2: Badania cementów wiertniczych oraz API SPEC 10 Specification for materials and testing for well cements.

Cykl badawczy, który został omówiony w dalszej części publikacji polegał na wykazaniu skuteczności działania opracowywanej hybrydowej cieczy buforowej. Dwufunkcyjne działanie tej cieczy polegało na usunięciu jak największej ilości osadu wytworzonego na powierzchni próbki skalnej, przy jednoczesnym zachowaniu przez ciecz parametrów cieczy buforowej, tj.: wyższa niż w przypadku cieczy przemywającej gęstość, parametry reologiczne cieczy buforowej oraz struktura cieczy pozwalająca na utrzymanie fazy stałej w całej objętości. Prace badawcze wykonano przy użyciu skonstruowanego w INiG - PIB symulatora przepływu cieczy wiertniczych (Kremieniewski e al., 2018c) (patent nr 233931). Urządzenie pozwala na symulowanie tłoczenia obiegu cieczy wiertniczych w układzie zamkniętym (rys. 3). Prace badawcze

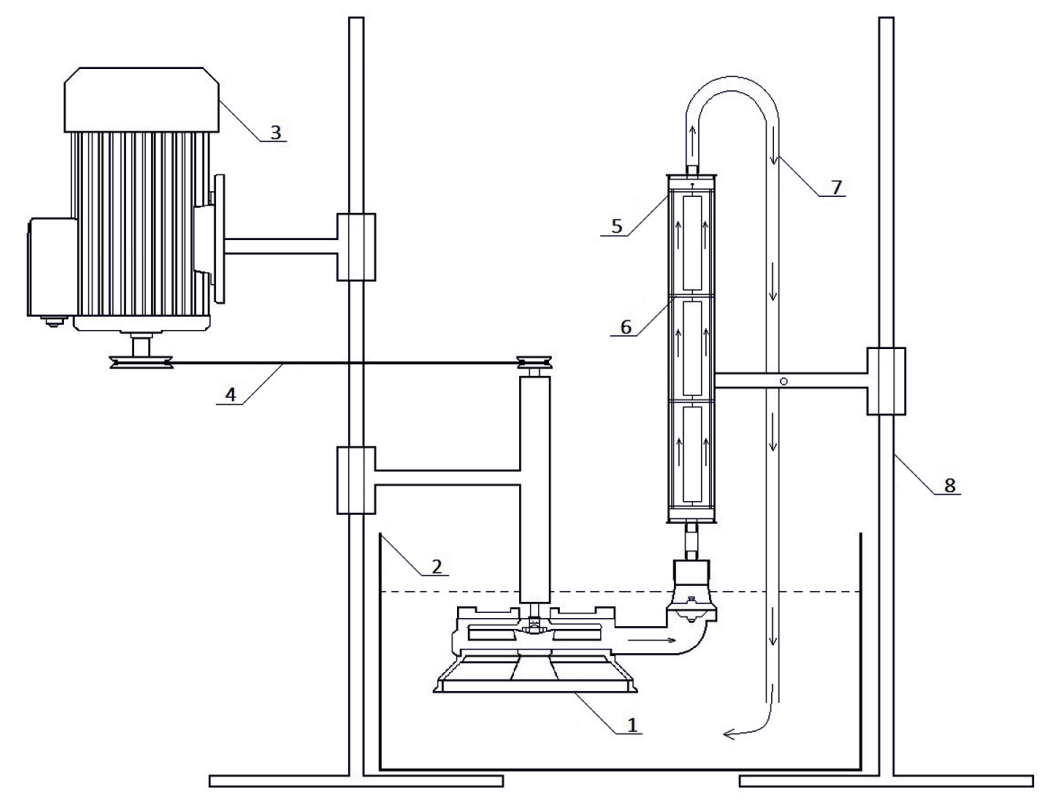

Rys. 3. Symulator przepływu cieczy wiertniczych - schemat

Fig. 3. Drilling fluid flow simulator - diagram 
przeprowadzone zostały przy stałej wartości wydatku tłoczenia (11,2 1/min) cieczy wiertniczych oraz jednakowym czasie kontaktu (4 minuty) cieczy z formacją skalną. Do badań użyto próbek piaskowca, które zostały wycięte w kształcie walca o średnicy zewnętrznej 25 mm i długości 60 mm (rys. 4). Rdzenie umocowano w statywie aparatury badawczej (rys. 5), który znajdował się wewnątrz rury z tworzywa (rys. 6), w której odbywał się przepływ cieczy wiertniczych. Układ taki symulował przestrzeń pierścieniową otworu wiertniczego.

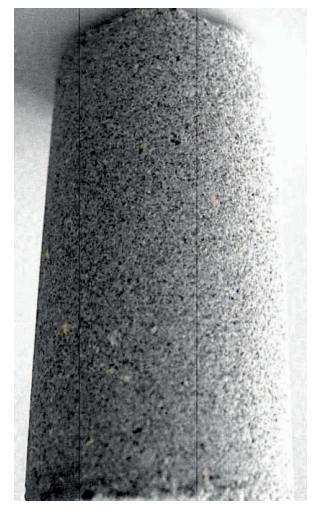

Rys. 4. Próbka rdzeniowa piaskowca Fig. 4. Core sandstone sample

Rys. 5. Schemat ułożenia rdzeni w statywie wewnątrz rury z tworzywa

Fig. 5. Diagram of core arrangement in a tripod inside a plastic pipe
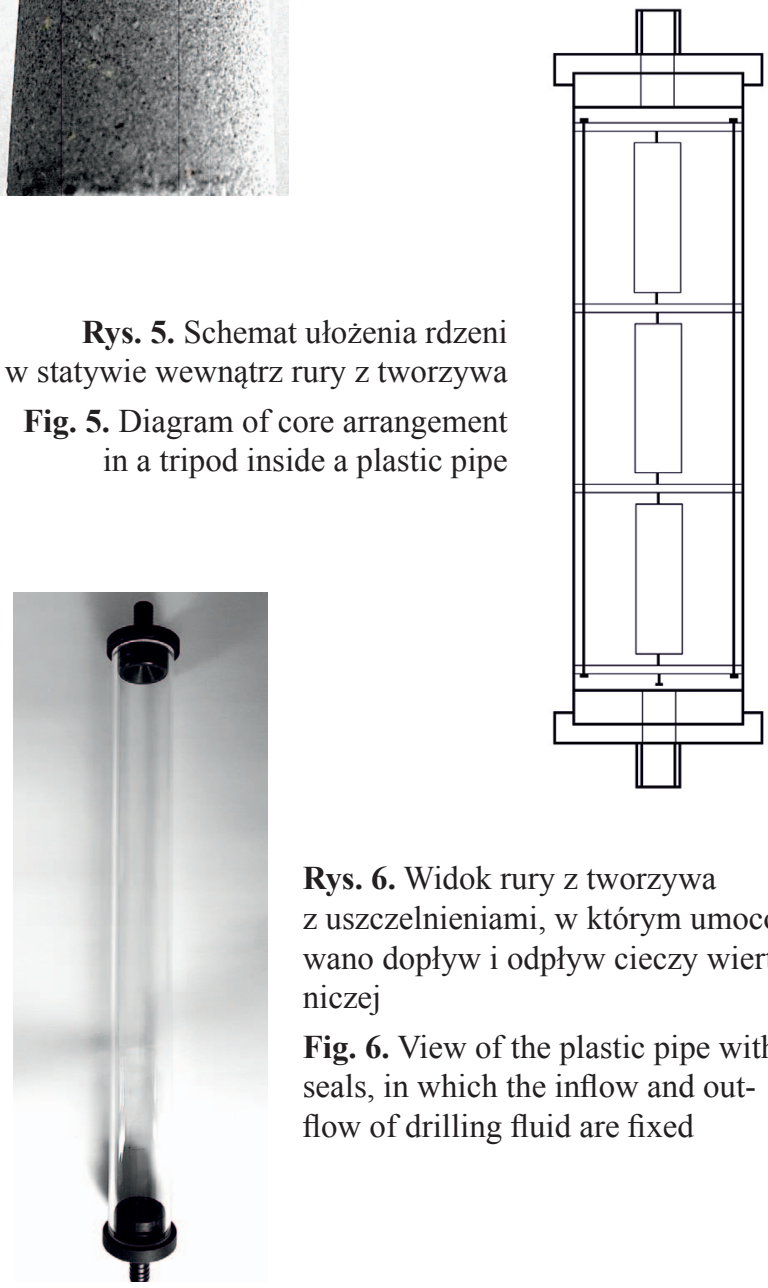

Rys. 6. Widok rury z tworzywa z uszczelnieniami, w którym umocowano dopływ i odpływ cieczy wiertniczej

Fig. 6. View of the plastic pipe with seals, in which the inflow and outflow of drilling fluid are fixed

Pierwszym etapem badań było wytworzenie na rdzeniach piaskowca (rys. 4) osadu płuczkowego. Polegało to na przetłoczeniu płuczki w symulowanej przestrzeni pierścieniowej i obmywaniu nią w czasie 1 godziny trzech rdzeni umieszczonych w urządzeniu. Płuczką użytą do tworzenia osadu była płuczka otworowa polimerowo-potasowa zawierająca zanieczyszczenia pochodzące z przewiercanych warstw. Parametry użytej płuczki pozwalały na uzyskanie trudno usuwalnego osadu. Następnym etapem było badanie skuteczności usuwania wytworzonego na powierzchni rdzenia osadu płuczkowego. Testy usuwania osadu przeprowadzono dla różnych cieczy wiertniczych: cieczy przemywających o stężeniu 0,2\% środka powierzchniowo czynnego, cieczy buforowej oraz nowoopracowywanej hybrydowej cieczy buforowej.

Według przyjętej na potrzeby badań metodyki możliwe było wyznaczenie skuteczności usuwania osadu płuczkowego przez hybrydową ciecz buforową na podstawie pomiaru przyczepności na kontakcie stwardniały zaczyn cementowy-formacja skalna. Próbki rdzeni piaskowca z utworzonym wcześniej osadem płuczkowym, po przemyciu wytypowaną do badań cieczą wiertniczą (ciecz przemywająca, ciecz buforowa, hybrydowa ciecz buforowa) zostały umieszczone $\mathrm{w}$ formie (rys. 7), a następnie zalane zaczynem cementowym. Po 48 godzinach hydratacji wykonano badanie przyczepności na kontakcie stwardniały zaczyn cementowy-rdzeń skalny. W celu określenia przyczepności próbkę umieszczano między dwiema płytami maszyny wytrzymałościowej (rys. 8), a następnie określano siłę zerwania przyczepności na kontakcie stwardniały zaczyn cementowy-skała pod wpływem obciążenia przykładanego na próbkę.

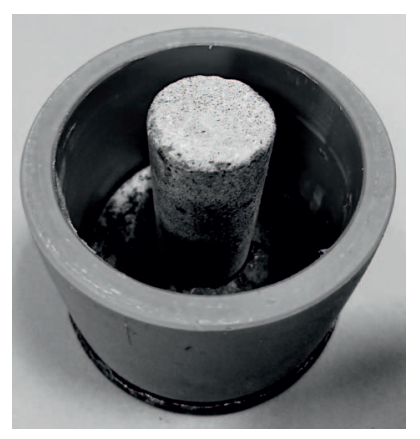

Rys. 7. Próbka rdzenia przygotowana do wypełnienia zaczynem cementowym

Fig. 7. Core sample prepared for filling with cement slurry

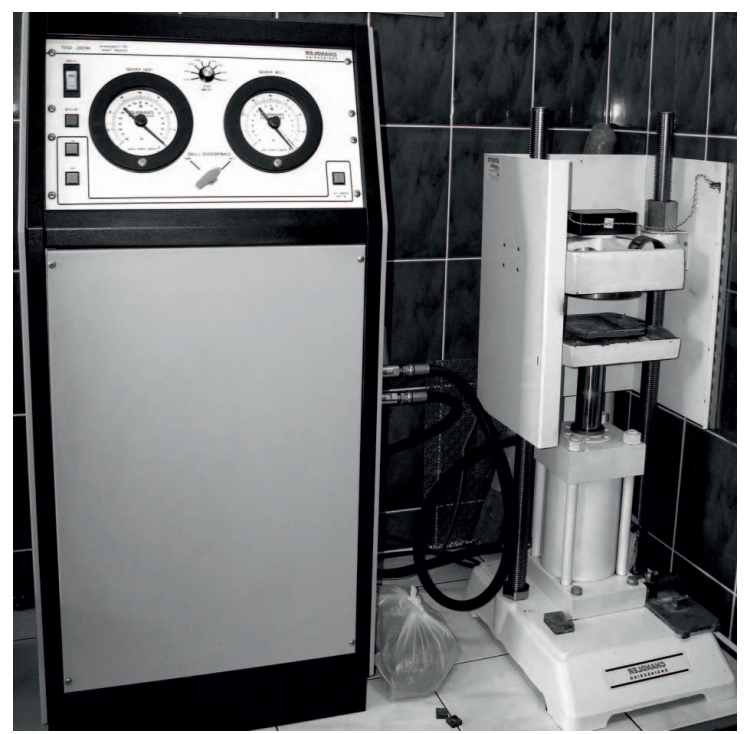

Rys. 8. Maszyna wytrzymałościowa

Fig. 8. Compression strength testing machine 
Naprężenie wyrażone w MPa potrzebne do pokonania wiązania stwardniałego zaczynu cementowego do formacji skalnej obliczono, według wzoru (1):

$$
\sigma_{p}=\frac{P}{S} \cdot 10^{-3}[\mathrm{MPa}]
$$

gdzie:

$\sigma_{p}$ - naprężenie zrywające wiązanie cementu ze skałą (umownie przyjęte jako przyczepność) [MPa],

$P$ - siła nacisku powodująca zerwanie połączenia stwardniałego zaczynu cementowego ze skałą [kN],

$s$ - powierzchnia styku próbki skały z zaczynem cementowym $\left[\mathrm{m}^{2}\right]$.

Bezpośrednio z wskaźnika maszyny wytrzymałościowej odczytywano siłę nacisku $(P)$, natomiast powierzchnia styku skały ze stwardniałym zaczynem cementowym wynikała z pola powierzchni zewnętrznej użytego do badań rdzenia i wysokości zaczynu cementowego w formie. W celu określenia maksymalnej i minimalnej przyczepności bazowej przeprowadzono dodatkowe badania przyczepności dla „czystego” rdzenia bez osadu płuczkowego oraz dla rdzenia z osadem płuczkowym bez przemywania (tab. 1). Do tych wartości (określanych mianem maksymalnej i minimalnej przyczepności bazowej) porównywano następne wyniki badań. Wszystkie rdzenie zalewano zaczynem cementowym o tym samym składzie i parametrach, które zamieszczono w tabeli 2.
Tabela 1. Bazowa przyczepność na kontakcie stwardniały zaczyn cementowy-skała

Table 1. Basic contact adhesion hardened cement slurry-rock

\begin{tabular}{|l|c|c|}
\cline { 2 - 3 } & $\begin{array}{c}\text { Sila zerwania } \\
\text { przyczepności }\end{array}$ & $\begin{array}{c}\text { Przyczepność } \\
\text { na kontakcie } \\
\text { stwardnialy zaczyn } \\
\text { cementowy-skala }\end{array}$ \\
\cline { 2 - 3 } & {$[\mathrm{kN}]$} & {$[\mathrm{MPa}]$} \\
\hline \hline $\begin{array}{l}\text { Maksymalna } \\
\text { przyczepność bazowa }\end{array}$ & 8,2 & 2,37 \\
\hline $\begin{array}{l}\text { Minimalna } \\
\text { przyczepność bazowa }\end{array}$ & 2,1 & 0,61 \\
\hline
\end{tabular}

W pierwszym etapie badań wykonano przemywanie utworzonego na powierzchni formacji skalnej osadu płuczkowego za pomocą cieczy przemywających o koncentracji 0,2\% środków powierzchniowo czynnych. Były to środki, które stosuje się podczas opracowywania cieczy przemywających. Na potrzeby niniejszej publikacji nazwy środków zostały zakodowane. Podczas pomiaru przyczepności na kontakcie stwardniały zaczyn cementowy-formacja skalna po wytworzeniu osadu oraz przemyciu poddanymi badaniom cieczami przemywającymi, uzyskano wartości w zakresie od 0,64 MPa do 0,72 MPa (tab. 3, rys. 9). Porównując te wartości do minimalnej przyczepności bazowej, która wynosiła 0,61 MPa, uzyskano wzrost wartości przyczepności w zakresie od 4,76\%

Tabela 2. Receptura i parametry zaczynu cementowego stosowanego w badaniu przyczepności na kontakcie stwardniały zaczyn cementowy-skała

Table 2. Recipe and parameters of cement slurry used for testing adhesion on contact hardened cement slurry-rock

\begin{tabular}{|c|c|c|c|c|c|c|c|c|c|c|c|}
\hline \multirow{2}{*}{\multicolumn{2}{|c|}{ Skład zaczynu }} & \multicolumn{10}{|c|}{ Parametry zaczynu } \\
\hline & & \multicolumn{8}{|c|}{ Gęstość [g/cm³] } & & 1,78 \\
\hline Woda & $\mathrm{w} / \mathrm{c}=0,45^{1}$ & \multicolumn{8}{|c|}{ Rozlewność [mm] } & & 240 \\
\hline Środek odpieniający & $0,5 \%$ & \multicolumn{8}{|c|}{ Odstój wody [\%] } & & 0,0 \\
\hline Środek upłynniający & $0,2 \%$ & \multicolumn{8}{|c|}{ Lepkość plastyczna [mPas] } & & 91,5 \\
\hline Środek antyfiltracyjny & $0,2 \%$ & \multicolumn{8}{|c|}{ Granica płynięcia $[\mathrm{Pa}]$} & & 6,48 \\
\hline Chlorek wapnia & $4,0 \%$ & \multicolumn{8}{|c|}{ Wytrzymałość strukturalna [Pa] } & & 2,88 \\
\hline Chlorek potasu (bwow²) & $3,0 \%$ & \multicolumn{8}{|c|}{ Filtracja $\left[\mathrm{cm}^{3} / 30 \mathrm{~min}\right]$} & & 36,0 \\
\hline Lateks & $10,0 \%$ & \multirow{2}{*}{\multicolumn{5}{|c|}{ Czas gęstnienia w temperaturze $25^{\circ} \mathrm{C}$}} & \multicolumn{3}{|c|}{ wartość 30 Bc [h:min] } & & $2: 55$ \\
\hline Stabilizator lateksu & $1,0 \%$ & & & & & & \multicolumn{3}{|c|}{ wartość $100 \mathrm{Bc}^{3}$ [h:min] } & & $3: 32$ \\
\hline Mikrocement & $10,0 \%$ & \multirow{2}{*}{\multicolumn{5}{|c|}{ Czas wiązania w temperaturze $20^{\circ} \mathrm{C}$}} & \multicolumn{3}{|c|}{ początek [h:min] } & & $4: 45$ \\
\hline Cement CEM I 32,5R & $100 \%$ & & & & & & \multicolumn{3}{|c|}{ koniec [h:min] } & & $5: 35$ \\
\hline Środek spęczniający & $0,3 \%$ & \multicolumn{5}{|c|}{ Wytrzymałość na ściskanie po 48 godz. [MPa] } & \multicolumn{5}{|c|}{10,6} \\
\hline \multirow{2}{*}{$\begin{array}{l}\text { Parametry reologiczne } \\
\text { temperaturze } 20^{\circ} \mathrm{C}\end{array}$} & $\mathrm{Obr} / \mathrm{min}$ & 600 & 300 & 200 & 100 & 60 & 30 & 6 & 3 & $10^{\prime \prime}$ & $10^{\prime}$ \\
\hline & Odczyt w [jf. $]^{4}$ & 187 & 105 & 74 & 44 & 27 & 17 & 6 & 4 & 6 & 16 \\
\hline
\end{tabular}

Ilości wszystkich środków prócz chlorku potasu podano procentowo w stosunku do ilości cementu

${ }^{1}$ w/c - współczynnik wodno-cementowy - stosunek masy wody do masy cementu

${ }^{2}$ bwow (ang. by weight of water) - w stosunku do ilości wody zarobowej

${ }^{3} \mathrm{Bc}$ - jednostka konsystencji gęstnienia zaczynu cementowego podczas pomiaru w konsystometrze

${ }^{4}$ j.f. - jednostki odczytane z wiskozymetru obrotowego fan 
Tabela 3. Wartości przyczepności na kontakcie stwardniały zaczyn cementowy-formacja skalna dla analizowanych cieczy wiertniczych Table 3. Adhesion values for contact hardened cement slurry-rock formation for the analyzed drilling fluids

\begin{tabular}{|c|c|c|c|c|}
\hline \multirow{2}{*}{$\begin{array}{l}\text { Stężenie procentowe i rodzaj } \\
\text { środka do sporządzenia cieczy } \\
\text { przemywającej }\end{array}$} & $\begin{array}{l}\text { Sila zerwania } \\
\text { przyczepności }\end{array}$ & $\begin{array}{c}\text { Przyczepność na kontakcie } \\
\text { stwardniały zaczyn } \\
\text { cementowy-skala }\end{array}$ & \multirow{2}{*}{$\begin{array}{l}\text { Procentowe obniżenie } \\
\text { przyczepności w sto- } \\
\text { sunku do maksymalnej } \\
\text { przyczepności bazowej }\end{array}$} & \multirow{2}{*}{$\begin{array}{l}\text { Procentowy wzrost } \\
\text { przyczepności w sto- } \\
\text { sunku do minimalnej } \\
\text { przyczepności bazowej }\end{array}$} \\
\hline & {$[\mathrm{kN}]$} & [MPa] & & \\
\hline Maksymalna przyczepność bazowa & 8,20 & 2,37 & - & - \\
\hline Minimalna przyczepność bazowa & 2,10 & 0,61 & - & - \\
\hline $0,2 \%$ SL22 & 2,20 & 0,64 & $73,17 \% \downarrow$ & $4,76 \% \uparrow$ \\
\hline $0,2 \% \mathrm{RD}$ & 2,25 & 0,65 & $72,56 \% \downarrow$ & $7,14 \% \uparrow$ \\
\hline $0,2 \% \mathrm{RB} 2$ & 2,30 & 0,67 & $71,95 \% \downarrow$ & $9,52 \% \uparrow$ \\
\hline $0,2 \%$ SL21 & 2,40 & 0,69 & $70,73 \% \downarrow$ & $14,29 \% \uparrow$ \\
\hline $0,2 \%$ RB7 & 2,50 & 0,72 & $69,51 \% \downarrow$ & $19,05 \% \uparrow$ \\
\hline $\begin{array}{l}\text { Bufor cementowy w/c }=1 \text { gęstość } \\
1450 \mathrm{~kg} / \mathrm{m}^{3}\end{array}$ & 1,50 & 0,43 & $81,71 \downarrow$ & $28,57 \% \downarrow$ \\
\hline Hybrydowa ciecz przemywająca $^{1}$ & 2,60 & 0,75 & $68,29 \% \downarrow$ & $23,81 \% \uparrow$ \\
\hline $0,2 \%$ RL 80 & 3,30 & 0,95 & $59,76 \% \downarrow$ & $57,14 \% \uparrow$ \\
\hline
\end{tabular}

${ }^{1}$ Hybrydowa ciecz buforowa - bufor cementowy $+0,2 \%$ RL $80+0,1 \%$ BB

*Niepewność mierzonych wielkości fizycznych zawartych w tabeli 3 oszacowano wg klasy dokładności urządzenia pomiarowego na poziomie 0,1\% (siła zerwania przyczepności)

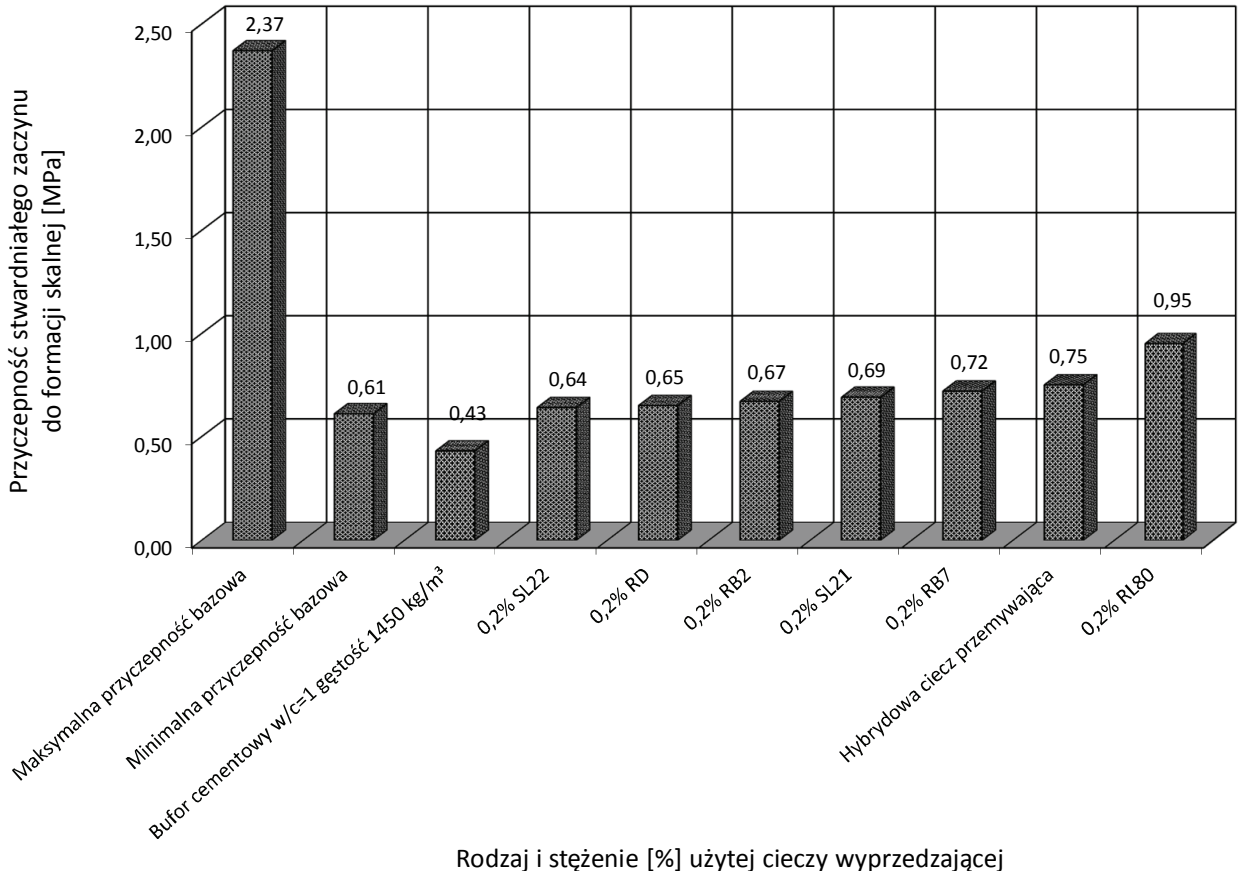

Rys. 9. Wartości przyczepności stwardniałego zaczynu cementowego do formacji skalnej

Fig. 9. Values of adhesion of hardened cement slurry to a rock formation a gęstość takiego buforu wynosi około $1450 \mathrm{~kg} / \mathrm{m}^{3}$, w zależności od rodzaju i uziarnienia zastosowanego cementu. Przetłoczenie standardowej cieczy buforowej skutkowało uzyskaniem podczas badań przyczepności równej 0,43 $\mathrm{MPa}$. Była to wartość niższa niż minimalna przyczepność bazowa i w porównaniu do tej wartości obniżenie przyczepności o 28,57\% (tab. 3 oraz rys. 10). Zaznaczyć należy, iż nie stosowano przed cieczą buforową cieczy przemywającej, natomiast w warunkach otworowych często tłoczona jest najpierw również ciecz przemywająca. Następnie wykonano badanie skuteczności usuwania osadu przez hybrydową ciecz buforową. Skład tej cieczy zawierał zarówno cement, jak i również środek powierzchniowo podczas przemywania cieczą na bazie środka SL22 do wartości 19,05\% podczas przemywania 0,2-proc. roztworem środka RB7. Wyniki zestawiono w tabeli 1 oraz na rysunku 10.

Następnie wykonano badanie skuteczności usuwania osadu płuczkowego z powierzchni formacji skalnej przez standardową oraz hybrydową ciecz buforową. Stosowany w warunkach otworowych bufor cementowy to ciecz wyprzedzająca o stosunku wodno-cementowym równym 1 , czynny oraz środek polimerowy pozwalający na utrzymanie fazy stałej w całej objętości cieczy buforowej. Po przetłoczeniu hybrydowej cieczy buforowej, z pominięciem podobnie jak poprzednio tłoczenia cieczy przemywającej uzyskano przyczepność wynoszącą 0,75 MPa. Porównując tą wartość do minimalnej przyczepności bazowej uzyskano wzrost wartości przyczepności na poziomie 23,8\% (tab. 3, rys. 10). Wykonane zostało również badanie skuteczności 


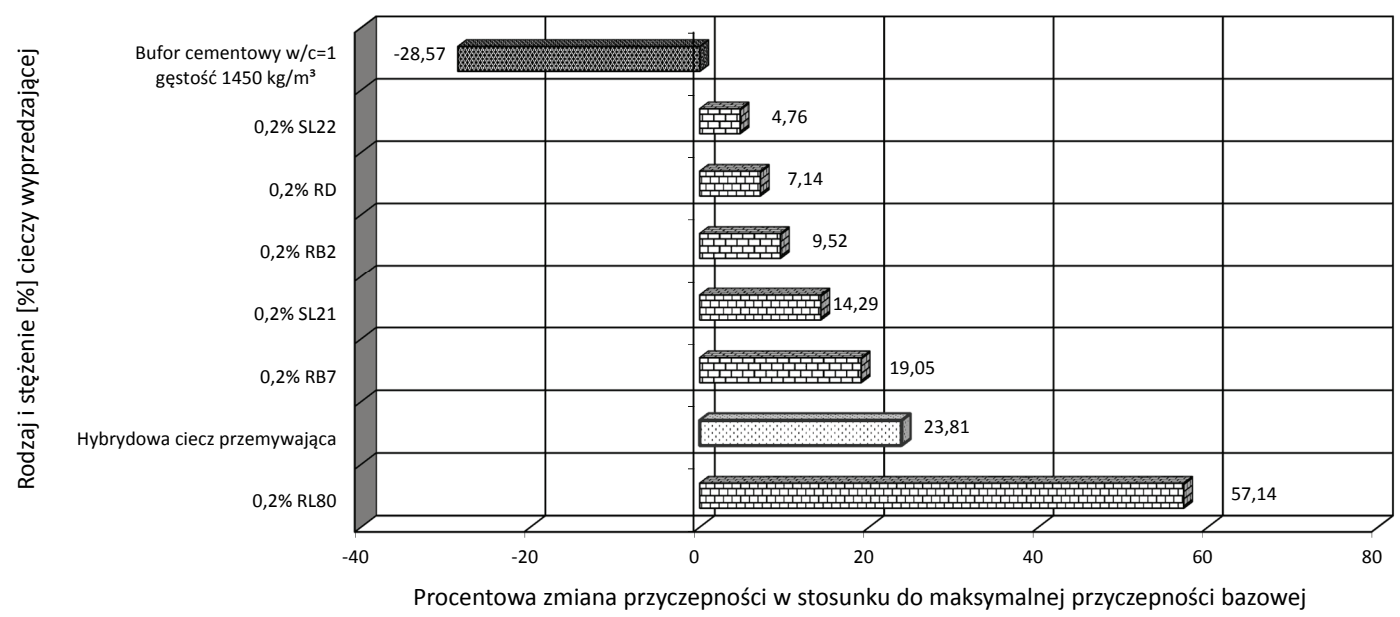

Rys. 10. Wartości procentowej zmiany przyczepności w stosunku do maksymalnej przyczepności bazowej

Fig. 10. The percentage of change in adhesion in relation to the maximum base adhesion jej kontaktu z cementem obecnym w cieczy buforowej (rys. 11). Powstała na powierzchni rdzenia warstwa zżelowanej płuczki wytworzyła ,płaszczyznę poślizgu", wynikiem czego było obniżenie wartości przyczepności. Takie działanie powoduje całkowity brak szczelności na kontakcie stwardniałego zaczynu z powierzchniami styku w otworze wiertniczym. Natomiast po zastosowaniu hybrydowej cieczy bu- usunięcia osadu płuczkowego przez nową ciecz przemywającą na bazie czystego środka użytego do sporządzania hybrydowej cieczy buforowej. Po przetłoczeniu cieczy przemywającej o koncentracji 0,2\% środka RL80 uzyskano ponad 57-proc. wzrost przyczepności w porównaniu do minimalnej przyczepności bazowej (tab. 3, rys. 10), co potwierdza wysoką skuteczność usuwania osadu przez daną ciecz.

\section{Podsumowanie}

W trakcie prowadzonych prac badawczych osad płuczkowy wytworzony na powierzchni formacji skalnej (próbka wzorcowa) był usuwany przez wytypowane ciecze przemywające o jednakowej 0,2\%-owej koncentracji środka powierzchniowo czynnego oraz ciecze buforowe. Badania podczas opracowywania hybrydowej cieczy buforowej zostały wykonane przy użyciu symulatora przepływu. Określono wpływ działania hybrydowej cieczy buforowej na skuteczność oczyszczenia przestrzeni pierścieniowej poprzez pomiar przyczepności na kontakcie stwardniały zaczyn cementowy-rdzeń skalny oczyszczony z utworzonego osadu płuczkowego.

Na podstawie analizy uzyskanych wyników badań stwierdzono wzrost przyczepności na kontakcie stwardniały zaczyn cementowy - formacja skalna. Świadczy to o poprawie skuteczności usunięcia osadu płuczkowego z formacji skalnej przy niewielkiej koncentracji środka powierzchniowo czynnego w cieczy przemywającej. Z kolei podczas próby usuwania osadu płuczkowego przez ciecz buforową zaobserwowano obniżenie wartości przyczepności znacznie poniżej wartości bazowej, którą to była przyczepność stwardniałego zaczynu do formacji skalnej przy braku usunięcia osadu. Taki wynik mógł być spowodowany mocnym żelowaniem płuczki podczas forowej uzyskano poprawę przyczepności, skutkującą wzrostem wartości w porównaniu do minimalnej przyczepności bazowej. Stwierdzić można, że znaczną rolę odgrywała tutaj wysoka skuteczność usuwania osadu przez użyty do sporządzania hybrydowej cieczy buforowej środek, jakim jest RL80, którego zastosowanie w przyjętej na potrzeby badań koncentracji pozwalało na uzyskanie ponad 57-proc. wzrostu

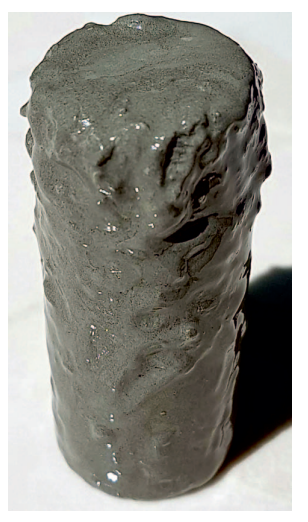

Rys. 11. Zżelowana warstwa płuczki na rdzeniu skalnym po przetłoczeniu standardowej cieczy buforowej

Fig. 11. Gelled scrubber layer on the rock core after pumping a standard spacer

wartości przyczepności w porównaniu do minimalnej przyczepności bazowej. Należy jednak zaznaczyć, iż zastosowanie samej cieczy przemywającej wymagać będzie użycia po niej cieczy buforowej w celu wyrównania parametrów reologicznych. Natomiast hybrydowa ciecz buforowa pozwala na skrócenie czasu przygotowania otworu do cementowania poprzez wyeliminowanie jednej operacji przed cementowaniem. Podczas prac badawczych, których celem było opracowanie hybrydowej cieczy buforowej uzyskane wartości przyczepności wydają się być zbyt niskie, dlatego też badania skuteczności usunięcia osadu przez hybrydową ciecz buforową wymagają dalszych prac. Niemniej jednak realizowane zagadnie może się przyczynić do zapoczątkowania lub uzupełnienia nowego kierunku badań nad opracowaniem hybrydowej cieczy buforowej. 


\section{Wnioski}

W trakcie badań nad opracowaniem hybrydowej cieczy buforowej oraz analizy efektywności działania tej cieczy wyciągnięto następujące wnioski:

- na podstawie uzyskanych wyników badań stwierdzono, że w dalszym ciągu najlepszą skuteczność usuwania osadu uzyskuje się przez zastosowanie cieczy przemywającej bez dodatku cementu;

- tłoczenie po płuczce cieczy buforowej z pominięciem tłoczenia cieczy przemywającej powoduje żelowanie płuczki i mocne skonsolidowanie osadu płuczkowego obecnego na powierzchniach formacji skalnej i rur okładzinowych;

- zastosowanie hybrydowej cieczy buforowej pozwala na poprawę usunięcia osadu z powierzchni formacji skalnej, jednak receptura tego rodzaju cieczy wyprzedzającej wymaga dopracowania;

- zawartość cementu w hybrydowej cieczy buforowej skutkuje obniżeniem skuteczności usuwania osadu płuczkowego z oczyszczanych powierzchni;

- podczas opracowywania hybrydowej cieczy buforowej należy rozważyć alternatywę zmiany cementu jako dodatku obciążającego ciecz na innego rodzaju dodatek, który nie powodowałby żelowania podczas kontaktu z płuczką wiertniczą;

- opracowanie hybrydowej cieczy buforowej o wysokiej skuteczności usuwania osadu może przyczynić się do skrócenia czasu przygotowania otworu do cementowania, obniżyć koszty związane ze stosowaniem dwóch rodzajów cieczy wyprzedzających oraz wpłynąć pozytywnie na środowisko z uwagi na mniejszą kubaturę stosowanej cieczy.

Prowadzone w warunkach laboratoryjnych badania skuteczności usuwania osadu nie w pełni odzwierciedlają faktyczny stan w warunkach otworowych, jednak skonstruowany symulator przepływu cieczy wiertniczych pozwala przybliżyć się do tych warunków.

Artykuł powstał na podstawie prac badawczych pt.: Analiza możliwości poprawy oczyszczenia przestrzeni pierścieniowej otworu wiertniczego przed zabiegiem cementowania - praca INiG - PIB na zlecenie MNiSW; nr zlecenia: 0058/KW/2017 nr archiwalny: DK-4100/0058/2017 oraz Analiza możliwości poprawy parametrów technologicznych zaczynu cementowego za pomoca domieszki grafenu - praca INiG - PIB na zlecenie MNiSW; nr archiwalny: DK-4100/0024/2020, nr zlecenia: 2400/KW/2020.

\section{Literatura}

Bakirov D.L., Burdyga V.A., Fattakhov M.M., Gritsay G.N., 2019. To the problem of the assessment of wells cementing quality. Oilfield Engineering, 9: 10-13. DOI: 10.30713/0207-2351-2019-9(609)-10-13.
Bakirov D.L., Burdyga V.A., Fattakhov M.M., Gritsay G.N., Antonov V.V., Belousov A.V., 2020. Increase of a well cementing stability to dynamic influence. Oilfield Engineering, 1: 65-70. DOI: 10.30713/0207-2351-2020-1(613)-65-70.

Błaż S., 2017. Nowe rodzaje cieczy przemywających osady z płuczki inwersyjnej przed zabiegiem cementowania otworów wiertniczych. Nafta-Gaz, 5: 302-311. DOI: 10.18668/NG.2017.05.02.

Curbelo F., Garnica A.I.C., Araujo, Edson \& Paiva E.M., Cabral A.G., Freitas J., 2018. Vegetable oil-based preflush fluid in well cementing. Journal of Petroleum Science and Engineering, 170: 392-399. DOI: 10.1016/j.petrol.2018.06.061.

Habrat S., Raczkowski J., Zawada S., 1980. Technika i technologia cementowań w wiertnictwie. Wydawnictwa Geologiczne, Warszawa.

Herman Z. (kier. zespołu), 1995a. Doskonalenie procesu cementowania rur okładzinowych w otworach wierconych przy użyciu płuczek: polimerowej z inhibitorem i polimerowej z inhibitorem kapsułującym w wybranych rejonach Karpat i przedgórza Karpat. Etap 01 - Opracowanie receptur zaczynów cementowych i technologii cementowania kolumn rur okładzinowych w wytypowanych rejonach wierceń w Karpatach Wschodnich. Archiwum Instytutu Nafty i Gazu - Państwowego Instytutu Badawczego, Kraków.

Herman Z. (kier. zespołu), 1995b. Doskonalenie procesu cementowania rur okładzinowych w otworach wierconych przy użyciu płuczek: polimerowej z inhibitorem i polimerowej z inhibitorem kapsułującym w wybranych rejonach przedgórza Karpat. Etap 02 - Opracowanie receptur zaczynów cementowych i technologii cementowania dla wybranych rejonów skał zbiornikowych przedgórza Karpat. Archiwum Instytutu Nafty i Gazu - Państwowego Instytutu Badawczego, Kraków.

Jasiński B., 2016. Ocena wpływu cieczy przemywających na jakość zacementowania rur w otworze wiertniczym po użyciu płuczki glikolowo-potasowej. Nafta-Gaz, 6: 413-421. DOI: 10.18668/ NG.2016.06.04.

Kędzierski M., Rzepka M., Kremieniewski M., 2019. Wpływ skażenia zaczynu cementowego płuczką wiertniczą i cieczą buforową na jego wiązanie. Nafta-Gaz, 11: 691-699. DOI: 10.18668/ NG.2019.11.04.

Kremieniewski M., 2016. Ograniczenie ekshalacji gazu w otworach wiertniczych poprzez modyfikację receptur oraz kształtowanie się struktury stwardniałych zaczynów uszczelniających. Prace Instytutu Nafty i Gazu - Państwowego Instytutu Badawczego, Kraków.

Kremieniewski M., 2018. Ocena skuteczności oczyszczania kolumny rur okładzinowych przed cementowaniem na podstawie badań przy użyciu wiskozymetru obrotowego. Nafta-Gaz, 9: 59-66. DOI: 10.18668/NG.2018.09.06.

Kremieniewski M., 2019a. Korelacja skuteczności usuwania osadu za pomocą cieczy na osnowie jonowych (anionowych) i niejonowych SPCz. Nafta-Gaz, 3: 38-48. DOI: 10.18668/NG.2019.0.3.

Kremieniewski M., 2019b. Receptury zaczynów do uszczelniania kolumn rur posadowionych w otworach wierconych w skałach chłonnych. Nafta-Gaz, 8: 451-457. DOI: 10.18668/NG.2019.08.01.

Kremieniewski M., 2019c. Korelacja wyników badań wytrzymałości na ściskanie i przyczepności do rur stalowych płaszcza cementowego z zaczynu o obniżonej gęstości. Nafta-Gaz, 10: 613-624. DOI: $10.18668 /$ NG.2019.10.03.

Kremieniewski M., 2020. Zmiana parametrów reologicznych zaczynu lateksowego pod wpływem dodatku mikrosfery. Nafta-Gaz, 1: 37-45. DOI: 10.18668/NG.2020.01.05.

Kremieniewski M., Kędzierski M. 2019. Badanie frakcjonowania lekkich materiałów obniżających gęstość jako wstępnego parametru podczas projektowania receptury zaczynu lekkiego. Nafta-Gaz, 12: 35-42. DOI: 0.18668/NG.2019.12.04. 
Kremieniewski M., Kędzierski M., Rzepka M., 2018b. Poprawa oczyszczenia przestrzeni pierścieniowej otworu wiertniczego przed zabiegiem cementowania. Prace Naukowe Instytutu Nafty i Gazu - Państwowego Instytutu Badawczego, 220: 1-172. DOI: 10.18668/PN2018.220.

Kremieniewski M., Kędzierski M., Rzepka M., 2018c. Symulator przepływu cieczy wiertniczych - zasada pomiaru i możliwości badawcze. Nafta-Gaz, 7: 46-53. DOI: 10.18668/NG.2018.07.05.

Kremieniewski M., Rzepka M., 2016. Przyczyny i skutki przepływu gazu w zacementowanej przestrzeni pierścieniowej otworu wiertniczego oraz metody zapobiegania temu zjawisku. Nafta-Gaz, 9: 722-728. DOI: 10.18668/NG.2016.09.06.

Kremieniewski M., Rzepka M., 2018. Hybrydowa ciecz przemywające do oczyszczania przestrzeni pierścieniowej otworu wiertniczego. Nafta-Gaz, 5: 372-379. DOI: 10.18668/NG.2018.05.04.

Kremieniewski M., Rzepka M., Kędzierski M., 2018a. Influence of the contact time of the preflush fluid with the filter cake on the effectiveness of the purification of the annular space. Nafta-Gaz, 1: 29-36. DOI 10.18668/NG.2018.01.03.

Kremieniewski M., Stryczek S., 2019 Zastosowanie cementu wysokoglinowego do sporządzania zaczynów uszczelniających w technologiach wiertniczych. Cement Wapno Beton, 3: 215-226.

Kremieniewski M., Stryczek S., Wiśniowski R., Gonet A., 2016. Zmniejszanie porowatości stwardniałych zaczynów wiertniczych poprzez wprowadzenie dodatków drobnoziarnistych. Cement Wapno Beton, 5: 325-335.

Moradi S.Sh., Nikolaev N.I., 2018. Developing spacer fluids to increase the well cementing quality. Construction of Oil and Gas Wells on Land and Sea, 7: 32-34. DOI: 10.30713/0130-3872-2018-7-32-34.

Nelson E.B. (ed.), 1990. Well Cementing. Schlumberger Educational Service, Houston, Teksas, USA.

Stryczek S., Gonet A., 2005. Kierunki ograniczania migracji gazu z przestrzeni pierścieniowej otworu wiertniczego. WUG, 3: 10-13.

Stryczek S., Kotwica Ł, Kremieniewski M., Rzepka M., UliaszMisiak B., Wiśniowski R., Złotkowski A., 2016. Studia nad doborem zaczynów uszczelniających w warunkach wierceń w basenie pomorskim. Wydawnictwo AGH, Kraków.
Uliasz M., Chudoba J., Herman Z., 2006. Płuczki wiertnicze z inhibitorami polimerowymi i ich oddziaływanie na przewiercane skały. Prace Instytutu Nafty $i$ Gazu, 139: 1-72.

Uliasz M., Zima G., Błaż S., Jasiński B., 2012. Systemy płuczek wiertniczych do wiercenia otworów w formacjach łupkowych. Rzeczpospolita łupkowa: studium wiedzy o gazie z formacji łupkowych. Prace Naukowe Instytutu Nafty $i$ Gazu, 183: 225-241.

Uliasz M., Zima G., Błaż S., Jasiński B., 2015. Ocena właściwości cieczy wiertniczych w aspekcie zapobiegania migracji gazu w otworach na przedgórzu Karpat. Nafta-Gaz, 1: 11-17.

Wang C., Xie F., Liu A., 2014. Discussion on the evaluation of preflush fluid for well cementing. Journal of the International Society of Sports Nutrition, 31: 92-94, 102. DOI: 10.3969/j. issn.1001-5620.2014.04.027.

Zima G., 2014. Wpływ właściwości płuczek wiertniczych na jakość cementowania w gazonośnych poziomach miocenu. Nafta-Gaz, 12; 899-907.

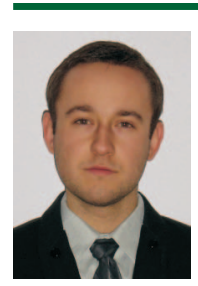

Dr inż. Marcin KREMIENIEWSKI

Adiunkt w Zakładzie Technologii Wiercenia

Instytut Nafty i Gazu - Państwowy Instytut Badawczy ul. Lubicz 25 A

31-503 Kraków

E-mail: marcin.kremieniewski@inig.pl

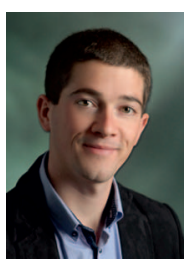

Mgr inż. Miłosz KĘDZIERSKI

Asystent w Zakładzie Technologii Wiercenia Instytut Nafty i Gazu - Państwowy Instytut Badawczy ul. Lubicz 25 A

31-503 Kraków

E-mail: milosz.kedzierski@inig.pl 